\title{
Xylopia aethiopica ethanol seed extract suppresses Cadmium chloride-induced ovary and gonadotropins toxicity in adult female Wistar rats
}

\author{
Elvis T Godam ${ }^{1}$, Olugbemi T Olaniyan², Chiwendu D Wofuru ${ }^{3}$, Clinton D Orupabo ${ }^{1}$, Kenneth S Ordu ${ }^{1}$, Barinua K \\ Gbaranor $^{4}$, Progress D Dakoru ${ }^{1}$ \\ ${ }^{1}$ Department of Human Anatomy, Faculty of Basic Medical Sciences, College of Medical Sciences, Rivers State \\ University, Port Harcourt, Nigeria \\ ${ }^{2}$ Laboratory for Reproductive Biology and Developmental Programming, Department of Physiology, Edo \\ University Iyamho, Nigeria \\ ${ }^{3}$ Department of Medical Laboratory Sciences, Faculty of Sciences, Rivers State University, Port Harcourt, Nigeria \\ ${ }^{4}$ Department of Human Physiology, Faculty of Basic Medical Sciences, College of Medical Sciences, Rivers State \\ University, Port Harcourt, Nigeria
}

\begin{abstract}
Objective: Xylopia aethiopica is a common plant in West Africa, with wide applications in trado-medical management of several diseases. Thus, our study aimed to analyze the histology and hormonal effects of ethanol extracts of Xylopia aethiopica seeds on cadmium chlorideinduced reproductive dysfunction in female Wistar rats.

Methods: We used twenty-five rats weighing 120$150 \mathrm{~g}$ for this study. The rats were divided into five groups $(n=5)$. Group 1: received only distilled water orally; Group 2: received $2 \mathrm{mg} / \mathrm{kg}$ cadmium chloride orally; Group 3: received $2 \mathrm{mg} / \mathrm{kg}$ cadmium chloride plus $50 \mathrm{mg} / \mathrm{kg}$ Xylopia aethiopica seeds orally; Group 4: received $2 \mathrm{mg} / \mathrm{kg}$ cadmium chloride plus $100 \mathrm{mg} / \mathrm{kg}$ Xylopia aethiopica seeds orally, and Group 5: received $100 \mathrm{mg} / \mathrm{kg}$ Xylopia aethiopica seeds only, orally. We administered the extracts for 14 days, after which we slaughtered the animals following chloroform anesthesia. We took the blood samples by cardiac puncture for hormonal assay. The ovaries and uterus were harvested for histology. We analyzed the data using ANOVA, and the differences in mean values were considered significant at $p<0.05$.

Results: The body weight of the rats showed a dose-dependent reduction $(p<0.05)$, compared with the controls. Xylopia aethiopica seeds significantly $(p<0.05)$ reversed the detrimental effects of Cadmium on $\mathrm{LH}$ and FSH. The histological analysis of the ovary showed significant improvement upon treatment with Xylopia aethiopica extract in a dose-dependent manner.

Conclusions: The ameliorative effects of Xylopia aethiopica against cadmium chloride-induced reproductive toxicity in female Wistar rats may be attributed to its antioxidant properties.
\end{abstract}

Keywords: Xylopia aethiopica, cadmium chloride, toxicity, gonadotropins, Wistar rats

\section{INTRODUCTION}

Pharmaceutical companies in the production of vaccines, drugs and other health supplements utilize plants and their derivatives. About $30 \%$ of modern drugs are derived from plant-based metabolites or biomolecules (Burns, 2000). Studies have shown that about $80 \%$ of the African population utilize traditional or medicinal plants as a major means of healthcare needs (Johnson et al., 2007). According to the World Health Organization, it has been estimated that about $75 \%$ of the world's population use herbal remedies, especially owing to the fact that it possess fewer side effects compared to orthodox drugs (Liu et al., 2007; Desai et al., 2009).

One of the several West and Central Africa plants with great therapeutic properties is Xylopia aethiopica, widely utilized by traditional medicine practitioners in the management of numerous diseases. Xylopia aethiopica is a slim tree, about $60-70 \mathrm{~cm}$ in diameter, $15-30 \mathrm{~m}$ tall, mainly found growing in the tropical forests of Ghana, Nigeria and Cameroon. The seeds outlines are noticeable from outside, and each pod holds about 5 to 8 kidneyshaped seeds with approximately $5 \mathrm{~mm}$ in length (John Kennedy et al., 2011). In Nigeria, it is commonly used as spice in the preparation of two special local soups named "Obe ata" and "Isi-ewu", grown widely in the Southern parts of Nigeria (Tairu et al., 2000). Traditionally, it has been utilized for inducing placental discharge postpartum, management of rheumatism, asthma, headache, bronchitis, neuralgia and colic pain (Woode et al., 2011). In addition, the fruit is applied in combination with other herbal remedies, like Piper nigrum, Capsicum frutescence plus Tetrepleura tetraptera for newly delivered mothers; it helps in uterine contraction (Durugbo, 2013). Studies have revealed that the fruit has anti-malaria, antibacterial and antifungal properties.

Cadmium chloride is an endocrine disruptor, with detrimental effects to the female reproductive system, and human exposure is usually through inhalation plus ingestion of contaminated products (Ansa et al., 2017). Cadmium chloride is discharged into the environment from different sources of industrial activities causing health hazard, and posing as environmental risk to both humans and animals (Orisakwe, 2014). Cadmium chloride levels in humans can be confirmed via blood, saliva, urine and organ analyses. The blood analysis detects recent exposures to cadmium while urine analysis detects accurately both recent and past exposures to cadmium (Jin et al., 2002). Cadmium chloride toxicity can affects multiple organs such as the kidneys, muscles, liver, reproductive system, lungs and the cardiovascular system (Dix-Cooper \& Kosatsky, 2018). Studies have revealed that cadmium chloride inhibits progesterone and estrogen production by blocking the gene expression of the steroidogenic acute regulatory protein StAR, plus cytochrome P450 cholesterol side chain enzyme P450scc (Pollack et al., 2014). This protein facilitates intra mitochondrial movement of cholesterol (Manna et al., 2016). Therefore, the aim of the study is to investigate the histology and hormonal effects of ethanol 
seed extracts of Xylopia aethiopica on cadmium chlorideinduced reproductive toxicity in female Wistar rats.

\section{MATERIALS AND METHODS}

We had twenty-five female Wistar rats weighing between 120-150g, from the Animal Housing facility, Department of Pharmacology, College of Medicine and Health Sciences, University of Port Harcourt, Nigeria. They were acclimatized for two weeks before starting the experiment, in accordance with the standard guide for the care and use of laboratory animals.

\section{Plant collection and Preparation}

Samples of the leaves and seeds were identified at the Herbarium of the Department of Biological Sciences, Ahmadu Bello University, Zaria, Nigeria, where the voucher specimen number 547 was deposited. The air-dried seeds of Xylopia aethiopica were extracted by cold maceration in ethanol, and evaporated to dryness on a rotary evaporator (rotavap R-200), at a reduced temperature.

\section{Experimental protocol}

The animals were randomly divided into five groups of five rats each, as follows: orally.

Group 1- control animals received only distilled water

Group 2- Animals given oral doses of $2 \mathrm{mg} / \mathrm{kg}$ body weight of cadmium chloride.

Group 3- Animals treated with $2 \mathrm{mg} / \mathrm{kg}$ body weight of cadmium chloride plus $50 \mathrm{mg} / \mathrm{kg}$ body weight of Xylopia aethiopica extract orally.

Group 4- Animals treated with $2 \mathrm{mg} / \mathrm{kg}$ body weight of cadmium chloride plus $100 \mathrm{mg} / \mathrm{kg}$ body weight of Xylopia aethiopica extract orally.

Group 5- Animals treated with $100 \mathrm{mg} / \mathrm{kg}$ body weight of Xylopia aethiopica extract only.

\section{Sample Collection}

We administered the extracts for 14 days after which, the animals were sacrificed following chloroform anesthesia. Blood samples were taken by cardiac puncture from all groups for hormonal assay (Follicle Stimulating Hormone and Luteinizing Hormone). The ovaries and uteri were harvested after abdominal incision, and then fixed in $10 \%$ buffered formalin. Tissue sections were prepared using routine histological tissue preparation. Photomicrographs were taken using the 5 mega pixel Amscope digital scope, mounted on an Olympus microscope.

Estimation of serum luteinizing hormone, and Follicle Stimulating Hormone

The serum samples obtained were analyzed to determine the concentrations of luteinizing hormone and follicle stimulating hormone. The analysis was carried out via the tube-based enzyme immunoassay (EIA) method.
The protocol used in hormone testing followed the method described by the kit manufacturers (Immunometrics Limited UK), and met the WHO research program standards for reproductive studies.

\section{Histological Analyses}

Histological investigations were carried out on the tissues fixed in $10 \%$ buffered formalin. The tissue blocks were sectioned for routine Hematoxylin and Eosin (H\&E) staining. The fixed organs were cut in about $0.5 \mathrm{~cm}$ crosssections and transferred to $70 \%$ alcohol for dehydration. The tissues were rinsed in $90 \%$ and absolute alcohol and xylene for different durations before they were transferred into two changes of molten paraffin wax for 1 hour each, in an oven at $65^{\circ} \mathrm{C}$ for infiltration. They were subsequently embedded and sliced in serial sections using a rotary microtome at five microns $(5 \mu)$. The tissues were transferred onto albumenized slides and allowed to dry on a hot plate for 2 minutes. The slides were dewaxed with xylene and passed through absolute alcohol (2 changes); $70 \%$ alcohol, $50 \%$ alcohol, and then water for 5 minutes. The slides were then stained with hematoxylin and eosin.

\section{Statistical Analysis}

The data was presented as mean values \pm SEM. ANOVA was carried out on the Statistical Package for the Social Sciences (SPSS package version 17) and we checked for the occurrence of significant differences between the results. Differences were considered significant at $p<0.05$.

\section{RESULTS}

Effects Xylopia aethiopica treatment on the body weight in Cadmium chloride-induced Reproductive toxicity in Wistar rats

The results obtained showed that Xylopia aethiopica treatment caused significant increase $(p<0.05)$ in the body weight compared with the control and cadmium chloride treated group (Table 1 ).

Effects Xylopia aethiopica treatment on the hormonal activity in Cadmium chloride-induced Reproductive toxicity in Wistar rats

The results obtained in Table 2 showed that the serum LH and FSH levels were significantly increased $(p<0.05)$ by treatment with Cadmium chloride while Xylopia aethiopica seeds extract showed a significant reduction in $(p<0.05)$ the level of $\mathrm{LH}$ and FSH.

Effects Xylopia aethiopica treatment on the histology in Cadmium chloride-induced Reproductive toxicity in Wistar rats

The results obtained from the photomicrograph sections (Figure 1) showed the control group with ovarian tissue having clear primary follicle (PF), secondary follicle (SF) and mature follicles (MF) with normal antrum,

Table 1. Effect of treatment with seed extracts of Xylopia aethiopica on body weight ( $\mathrm{g}$ ) in Cadmium chloride-induced Reproductive toxicity in Wistar rats.

\begin{tabular}{|l|c|c|c|c|}
\hline Group & Week 1 & Week 2 & Week 3 & Week4 \\
\hline Group 1 & $83.40 \pm 2.66$ & $101.80 \pm 2.52$ & $139.00 \pm 1.87$ & $143.40 \pm 2.14$ \\
\hline Group 2 & $89.00 \pm 2.80$ & $106.00 \pm 1.87$ & $120.00 \pm 2.55^{\mathrm{a}}$ & $100.00 \pm 1.87^{\mathrm{a}}$ \\
\hline Group 3 & $86.40 \pm 3.23^{\mathrm{b}}$ & $99.20 \pm 2.96^{\mathrm{b}}$ & $114.00 \pm 1.87^{\mathrm{b}}$ & $99.20 \pm 1.66^{\mathrm{b}}$ \\
\hline Group 4 & $86.00 \pm 6.00$ & $104.60 \pm 5.58$ & $122.00 \pm 3.39^{\mathrm{b}}$ & $111.80 \pm 2.46^{\mathrm{b}}$ \\
\hline Group 5 & $87.00 \pm 5.39$ & $104.40 \pm 3.06$ & $129.400 \pm 1.69$ & $120.00 \pm 4.11$ \\
\hline
\end{tabular}

Values are expressed as mean \pm SEM,

$\mathrm{n}=5$.

a,bdenote significant variation $(p<0.05)$ when compared with control and cadmium chloride groups. 
Table 2. Effect of treatment with seeds extracts of Xylopia aethiopica on hormonal activity in Cadmium chlorideinduced Reproductive toxicity in Wistar rats

\begin{tabular}{|c|c|c|}
\hline \hline Group & FSH $(\mathbf{m I U} / \mathbf{m L})$ & LH $(\mathbf{m I U} / \mathbf{m L})$ \\
\hline Group 1 & $0.24 \pm 0.02$ & $0.26 \pm 0.03$ \\
\hline Group 2 & $6.25 \pm 0.70^{\mathrm{a}}$ & $6.11 \pm 0.75^{\mathrm{a}}$ \\
\hline Group 3 & $3.41 \pm 0.03^{\mathrm{b}}$ & $3.30 \pm 0.04^{\mathrm{b}}$ \\
\hline Group 4 & $0.16 \pm 0.02^{\mathrm{b}}$ & $0.17 \pm 0.02^{\mathrm{b}}$ \\
\hline Group 5 & $0.15 \pm 0.03^{\mathrm{a}}$ & $0.15 \pm 0.03^{\mathrm{a}}$ \\
\hline
\end{tabular}

Values are expressed as mean \pm SEM,

$\mathrm{n}=5$.

a,bdenote significant variation $(p<0.05)$ when compared with control and cadmium chloride groups.

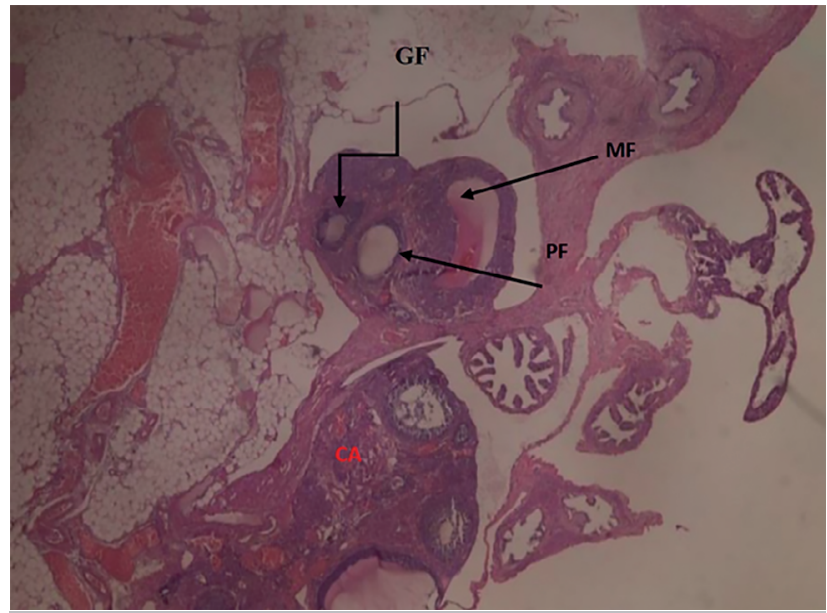

Figure 1. Photomicrograph section of a normal control showing ovarian tissue with primary follicle (PF), secondary follicle (SF) and mature follicles (MF) with antrum, with granulosa and theca cells. There is corpus albicans (CA) and blood vessels showing normal ovarian activity. H\&E $\times 100$

granulosa and theca cells. There is also corpus albicans (CA) and blood vessels showing normal ovarian activity. Figure 2 shows a photomicrograph section of ovary from the cadmium-treated group, only showing severe tissue necrosis and follicular cell degeneration (FCD), as well as atresia and no formation of new follicles. There is total degeneration of follicular cells, with no significant ovarian activity. Images from treatments with Xylopia aethiopica extracts revealed an increasing number of primary and secondary follicles, as well as other cellular constituents. The increase was dose-dependent as higher doses of extracts presented with a larger number of regenerating cellular constituents (Figure 3, 4, 5).

\section{DISCUSSION}

The findings showed a significant body weight reduction $(p<0.05)$ with the cadmium chloride-treated group which became progressive with the duration of administration. This is in agreement with the findings of Osifo \& Iyawe (2018). Varying doses of Xylopia aethiopica seeds extract showed a significant increase $(p<0.05)$ in body weight. Studies by Singh et al. (2011) revealed that oxidative stress could be the cause of the weight reduction seen with cadmium chloride toxicity. Therefore, the weight reduction found in this study could be attributed to oxidative stress

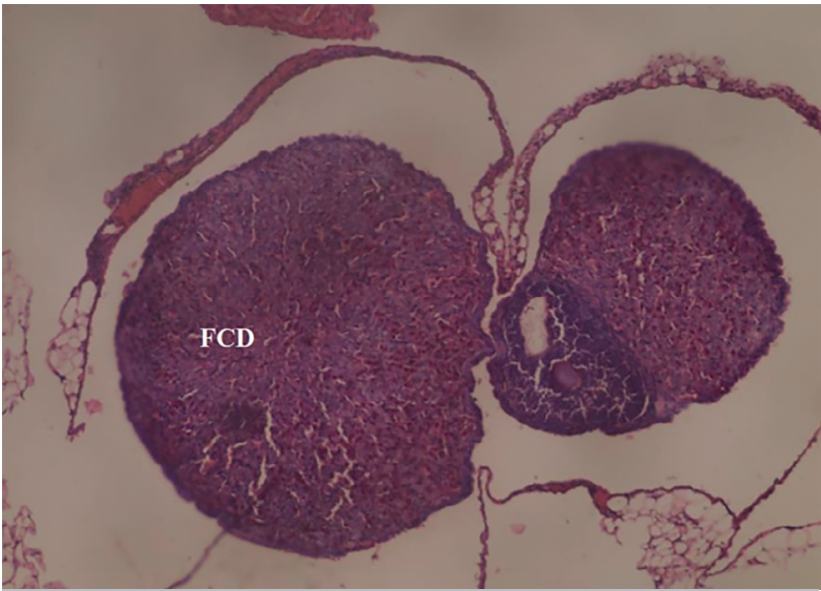

Figure 2. Photomicrograph section of ovary from Cadmium treated group showing severe tissue necrosis and follicular cell degeneration (FCD), atresia and no formation of new follicles. There is total degeneration of follicular cells with no significant ovarian activity. H\&E $\times 100$

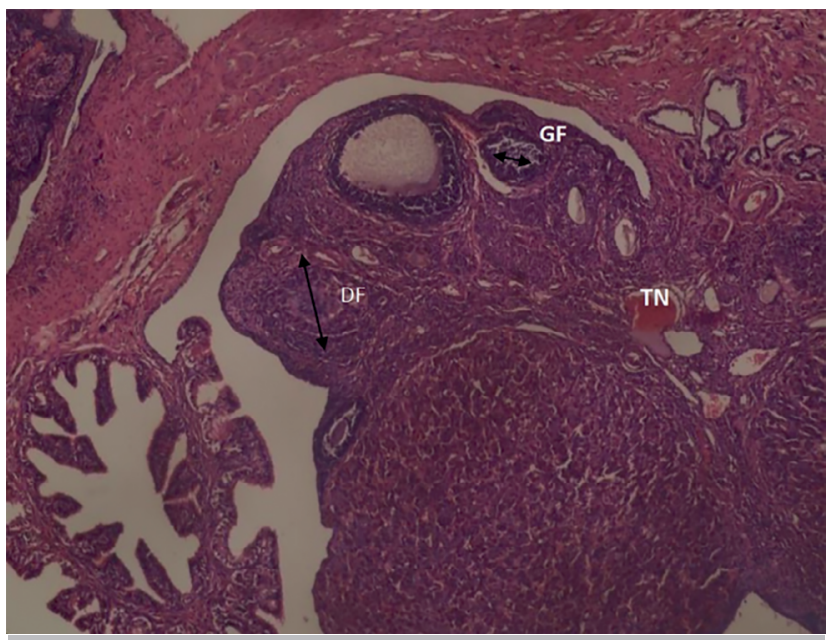

Figure 3. Photomicrograph section from he group treated with $2 \mathrm{mg} / \mathrm{kg}$ bw cadmium plus $50 \mathrm{mg} / \mathrm{kg}$ bw of $X$. aethiopica, showing few germinal follicles, primary follicle and numerous degenerated follicles with connective tissue necrosis (TN). H\&E $\times 100$

following cadmium chloride toxicity, affecting the brain function, nutritional uptake in the gastrointestinal system and metabolic activities. The significant weight gain seen in the Xylopia aethiopica seeds extract treated group could probably be the result of its ability to reduce the oxidative stress induced by cadmium chloride plus its high content in carbohydrates and phytochemicals like alkaloids, terpenoids, polyphenols, kauranes (a type of diterpenes, called xylopic acid and kaurenoic) (Omeh et al., 2014).

The results obtained for the hormonal analysis showed a significant increase $(p<0.05)$ in serum levels of FSH and $\mathrm{LH}$ in the groups treated with cadmium chloride, compared to the control group (Table 2 ). This could be the result of a negative feedback mechanism of reduced progesterone and estrogen levels from the ovarian tissues due to the detrimental impact of cadmium chloride toxicity. This is in agreement with findings from DixCooper \& Kosatsky (2018), who revealed that cadmium 


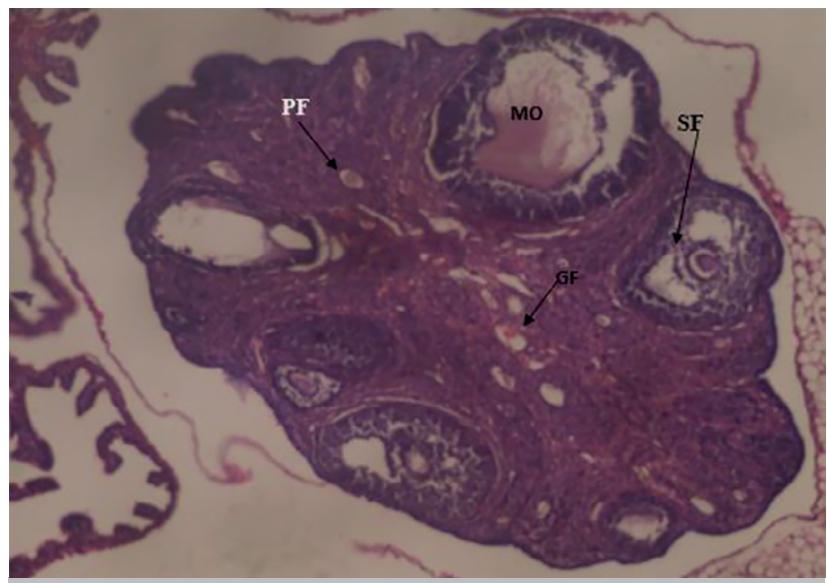

Figure 4. Photomicrograph section of ovarian tissue from the group treated with $100 \mathrm{mg} / \mathrm{kg}$ bw $X$. aethiopica seed extract showing tissue protection with primary follicles (PF), secondary follicles (SF) and mature oocytes (MO). There are new germinating follicular cells (GF). This demonstrates ovarian tissue protection against cadmium-induced cellular damage. H\&E x100

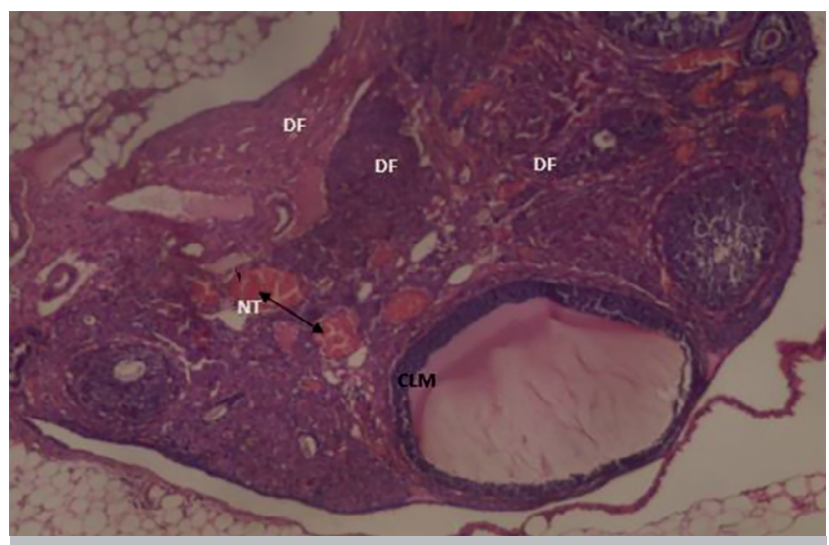

Figure 5. Photomicrograph section of ovarian tissue from $100 \mathrm{mg} / \mathrm{kg}$ bw $X$. aethiopica seeds extract-treated group only showing mature oocyte, primary and secondary follicles (DF) H\&E x 100

chloride alters steroidogenesis, induces pregnancy loss, causes disorders of the menstrual cycle and reproductive hormones, delayed puberty (Chedrese et al., 2006; Gallagher \& Kovach, 2010). However, contrary to the work of Nampoothiri \& Gupta (2006), who showed that cadmium chloride significant decreases gonadotrophin levels, thereby disrupting the activities of steroidogenic enzymes. Although this discrepancy may be the result of the study duration, the route of administration and the dose of cadmium chloride administered. The groups receiving seed extracts of $X$. aethiopica showed a significant reduction in gonadotrophins (Table 2). These finding is consistent with the study from Nnodim et al. (2013), who revealed that $80 \mathrm{mg} / \mathrm{kg}$ of $X$. aethiopica dried fruit extract caused a significant reduction in FSH levels in male Wistar rats, and also the study from Onuka et al. (2017), who reported that $X$. aethiopica extract caused a significant reduction in serum LH level during the proestrus and estrus phases, and attributed the action of the extract to the high content of saponins, having the ability to block the release of LH from gonadotropes. These findings may be a result of the
$X$. aethiopica antioxidant ability to reduce the oxidative stress induced by cadmium chloride. Several studies have revealed the detrimental role of oxidative stress in causing hormonal imbalance and dysfunctions, or acted via the inhibition of the rate-limiting enzyme, HMG-CoA reductase, in the biosynthesis of cholesterol, which is the precursor molecule for all steroid hormones. HMG-CoA reductase catalyze the conversion of HMG-CoA to mevalonic acids (Omeh et al., 2014).

Results from the histological analysis revealed that tissue protection with primary follicles, secondary follicles and mature oocytes as well as the formation of germinating follicular cells has been demonstrated in all the groups treated with $X$. aethiopica. This improvement is seen to be dose-dependent.

\section{CONCLUSION}

This study has shown that $X$. aethiopica has ameliorative effect against cadmium chloride on ovary. These effects may be attributed to its antioxidants property. Further studies should be carried out to isolate the active components responsible for this antioxidant effect and to evaluate the likely mechanism of action.

\section{Disclosure}

The authors reported no potential conflict of interest

\section{Corresponding Author:}

Olugbemi T Olaniyan

Laboratory for Reproductive Biology and Developmental Programming

Department of Physiology

Edo University Iyamho

Edo State, Nigeria.

Email: olaniyan.olugbemi@edouniversity.edu.ng

\section{REFERENCES}

Ansa AA, Akpere O, Imasuen JA. Semen traits, testicular morphometry and histopathology of cadmium-exposed rabbit bucks administered methanolic extract of Phoenix dactylifera fruit. Acta Sci Anim Sci. 2017;39:207-15. DOI: 10.4025/actascianimsci.v39i2.32858

Burns MM. Alternative medicine: herbal preparation. Clin Pediatr Emerg Med. 2000;1:186-90. DOI: 10.1016/S15228401(00)90026-0

Chedrese PJ, Piasek M, Henson MC. Cadmium as an endocrine disruptor in the reproductive system. Immun Endoc Metab Agents Med Chem. 2006;6:27-35. DOI: $10.2174 / 187152206775528941$

Desai N, Sharma R, Makker K, Sabanegh E, Agarwal A. Physiologic and pathologic levels of reactive oxygen species in neat semen of infertile men. Fertil Steril. 2009;92:1626-31. PMID: 18937945 DOI: 10.1016/j. fertnstert.2008.08.109

Dix-Cooper L, Kosatsky T. Blood mercury, lead and cadmium levels and determinants of exposure among newcomer South and East Asian women of reproductive age living in Vancouver, Canada. Sci Total Environ. 2018;619-20:1409-19. PMID: 29734617 DOI: $10.1016 / \mathrm{j}$. scitotenv.2017.11.126

Durugbo EU. Medico-ethnobotanical inventory of Ogii, Okigwe Imo State, South Eastern Nigeria. Glob Adv Res J Med Plants. 2013;2:30-44. 
Gallagher CM, Moonga BS, Kovach JS. Cadmium, folliclestimulating hormone, and effects on bone in women age 42-60 years, NHANES III. Environ Res. 2010;110:105- 11. PMID: 19875111 DOI: 10.1016/j.envres.2009.09.012

Jin $T$, Nordberg $M$, Frech $W$, Dumont $X$, Bernard A, Ye $T$, Kong Q, Wang Z, Li P, Lundström NG, Li Y, Nordberg GF. Cadmium biomonitoring and renal dysfunction among a population environmentally exposed to cadmium from smelting in China (ChinaCad). Biometals. 2002;15:397410. PMID: 12405535 DOI: 10.1023/A:1020229923095

Johnkennedy N, Emejulu A, Amaechi A, Chukwunyere $\mathrm{NE}$. Influence of Xylopia Aethiopica fruits on some hematological and biochemical profile. Al Ameen J Med Sci. 2011;4:191-6.

Johnson Q, Syce J, Nell H, Rudeen K, Folk WR. A randomized, double-blind, placebo-controlled trial of Lessertia frutescens in healthy adults. PLoS Clin Trials. 2007;2:e16. PMID: 17476314 DOI: 10.1371/journal. pctr.0020016

Liu GQ, Wang XL, Yang Q, Wei, M. Advances in studies on chemical constituents and pharmacological actions of Cordyceps sinensis. Food Sci Technol. 2007;32:202-9.

Manna PR, Stetson CL, Slominski AT, Pruitt K. Role of the steroidogenic acute regulatory protein in health and disease. Endocrine. 2016;51:7-21. PMID: 26271515 DOI: $10.1007 / \mathrm{s} 12020-015-0715-6$

Nampoothiri LP, Gupta S. Simultaneous effect of lead and cadmium on granulosa cells: a cellular model for ovarian toxicity. Reprod Toxicol. 2006;21:179-85. PMID: 16159707 DOI: $10.1016 /$ j.reprotox.2005.07.010

Nnodim JK, Nwanjo HU, Okolie NJ, Opara AU, Nwosu DC, OKoroiwu I, Dike J, Okorie H, Nwadike CN, Uduji HI. Effects of Xylopia Aethiopica fruits on reproductive hormonal level in rats. Global J Med Plant Res. 2013;1:29-31.
Omeh YN, Onoja SO, Ezeja MI, Bassey S, Ogbenta G, Adetayo AB. Phytochemical, nutrient composition and serum lipid lowering effect of Xylopia aethiopica fruit. $\mathrm{Br}$ J Pharm Res Int. 2014;4:2096-105. DOI: 10.9734/ BJPR/2014/12392

Onuka AE, Okechukwu NC, Maxine KM. A comparative study between Xylopia aethiopica dried fruit extract and ibuprofen inhibiting effects on some reproductive hormones irrespective of the estrous cycle. Int J Complement Alt Med. 2017;8:00274. DOI: 10.15406/ijcam.2017.08.00274

Orisakwe OE. Lead and cadmium in public health in Nigeria: physicians neglect and pitfall in patient management. N Am J Med Sci. 2014;6:61-70. PMID: 24696827 DOI: 10.4103/1947-2714.127740

Osifo CU, Iyawe VI. Cadmium exposure induces early catabolism in male Wistar rat experiment. J Mol Cell Biochem. 2018;2:1-6.

Pollack AZ, Ranasinghe S, Sjaarda LA, Mumford SL. Cadmium and reproductive health in women: a systematic review of the epidemiologic evidence. Curr Environ Health Rep. 2014;1:172-84. PMID: 27453808 DOI: 10.1007/ s40572-014-0013-0

Singh N, Bhalla M, Jager P, Gilca $M$. An overview on ashwagandha: a Rasayana (rejuvenator) of Ayurveda. Afr J Tradit Complement Altern Med. 2011;8:208-13. PMID: 22754076 DOI: 10.4314 /ajtcam.v8i5S.9

Tairu AO, Hofmann T, Schieberle P. Characterization of the key aroma compounds in dried fruits of the West African peppertree Xylopia aethiopica (Dunal) A. Rich (Annonaceae) using aroma extract dilution analysis. J Agric Food Chem. 1999;47:3285-7. PMID: 10552646 DOI: $10.1021 /$ jf990228+

Woode E, Alhassan A, Abaidoo CS. Effect of ethanolic fruit extract of Xylopia aethiopica on reproductive function of male rats. Int J Pharm Biomed Res. 2011;2:161-5. 